\title{
The Imagined Return Community of Guatemalan Refugees
}

\author{
Finn Stepputat
}

As Benedict. Anderson said, nation states are "imagined communities" in the sense that a limited number of individuals are defined as members of a nation which is conceived as "a deep horizontal comradeship" regardless of existing inequalities and differences (Anderson 1983). The fact that the Guatemalan state was never able to incorporate its Indian peoples into an imagined, national community is a necessary key to the understanding of the violent conflict which forced more than one hundred thousand Guatemalans-mostly Indians-to leave the country between 1981 to 1983 . Since 1993, large, well organized groups from the forty-five thousand assisted camp refugees have begun to return. I shall argue here that an "imagined return community" has developed in the camps despite existing differences among the refugees and the fact that they have been located in a large number of geographically dispersed camps.

\section{State and Community in Guatemala}

Over the colonial period, the Indians in Guatemala developed a distinct identity closely related to the local community, or more precisely, to the township to which they belonged. Local communities were moulded by the colonial administration as a measure of control and division which reduced the risk of regional Indian revolts (Smith 1977). Segregation was an important technique of colonial rule, and even though ladinos (that is people of Spanish origin or mestizos who adopted non-Indian culture) began to occupy the centres of urban townships during the nineteenth century, Guate-

Finn Stepputat, Ph.D., is based at the Centre for Development Research, Copenhagen, Denmark. This article is based on two field studies in a refugee settlement in Campeche, Mexico, in 1988 and 1990. malan society remained highly segregated in spatial, social and cultural terms. Today, more than 90 percent of the population in rural highland townships are registered as being indigenous.

The community became an important element of Indian political life which helped them retain relative autonomy vis-à-vis the ladino structure of domination (Smith 1990). To some extent, state power remained external to the community, and attempts to assimilate Indians into the national culture were unsuccessful; thus, Indian communities are often described as "closed" and "corporate" entities (Wolf 1957).

Indians maintained a strong local identity which, until the 1970s, appeared to be more important than other identities. Those who fled to Mexico were categorized as "Guatemalan refugees," but to many of them nationhood (not to mention refugeehood) made little sense from the outset. They constructed their own meaning of "Guatemalan," which differed slightly from the conventional: "We call ourselves Guatemalans, but we have not even been there" (i.e., to Guatemala City). In their definition, "nation" sometimes refers to township, as in "we come from many different nations." Refugees often refer to themselves and others as, for example, Miguelenos (from San Miguel) or Cobáneros (from Cobán) rather than, for example, using linguistic categories such as Maya, Kanjobal and Kekchi. This concept of local identity persists no matter how many years they have lived away from the community where they were born.

Being in a refugee camp, the observer may be stricken by the diversity of pre-flight experiences, languages, religious affiliations, economic assets, etc. Nevertheless, the assisted refugees have developed a distinct set of discourses and practices-the culture of an imagined return communitywhich is nurtured by the collective experience of living in exile. It is not an all-encompassing culture, the membership of the community is blurred, and it is fraught with disagreements and conflicts, but the effects are tangible.

\section{La Tristeza and the Dilemma of Exile}

Edward Said once described exile as an "unhealable rift forced between... the self and its true home," a break which is marked by an "essential sadness" or "the crippling sorrow of estrangement" (Said 1984). In the case of the Guatemalan refugees he seems to have hit the nail on the head. La tristeza, the sorrow or sadness, permeates their representations of how it is to be a refugee:

"Here people are sad."

"Remembering makes me sad."

"When we have a fiesta we forget the sorrow a little, and we forget how our country is."

In less general terms, Guatemalan refugees recurrently use the metaphor of posada when talking about conditions of exile: "We asked posada with the Mexicans" or "thanks to the Mexicans who have given us posada..." Posada is a shelter, lodge or hostel: to ask posada at the homes of acquaintances or strangers used to be a familiar custom among merchants when they were away from their home towns. As described by Redfield the custom of "asking posada" has the double meaning of being away from home and having a detached relationship to people who give posada (Redfield 1939).

The metaphor thus describes an experience of transience and detachment among Guatemalan refugees. In this aspect, they seem to share their experience with many other refugee groups. In a way, the construction of nation states implies that refugees, strangers to the nation state by definition, are 
thought of as future returnees; they are "out of place" and are usually expected to return when conditions allow.

While the Mexican government has declared that registered refugees can stay as long as they want to, the refugees themselves have perceived a number of political, juridical and economic pressures for repatriation. Clearly, the Mexican government favours the repatriation solution, and no measures have been taken to grant refugees permanent legal status in Mexico. However, time may solve the problems as refugee children born in Mexicoare grantedMexican citizenship.

Expressions of dispossession and insecurity abound when the refugees talk about their conditions:

\footnotetext{
"We left everything behind when we fled; we arrived poor, with empty hands, to Mexico."

"Here you have no security; if you die, your wife and children are left on their own; we leave nothing here." "We're only surviving here because the Mexicans lend us land, but how long will it last?"

"It's the doubts that make life hard."
}

Since their legal status does not permit them to own land, refugees have to work, rent or sharecrop the land of others in order to survive. In a slightly different form, they use the metaphor of posada to describe this specific relationship to land, which is very common in Guatemala:

Here [in Mexico] we are posados in the land of others as we were before -in the cold land [i.e., highland Guatemala]... They will not give us documents to the land we are working. We will have no security here, either.

While some refugees have decided to stay in Mexico in spite of these conditions, others have repatriated to Guatemala; they were "tired of waiting." The rest, the majority, has been waiting for conditions to improve in Guatemala. But the dilemma of exile is not the only factor in the choice between staying or going back; since 1986, a major source of debate and disagreement among the refugees has been how the refugees should go back to Guatemala.

\section{Return versus Repatriation}

When a civilian government was installed in Guatemala in 1986, the UNHCR made a tripartite agreement on voluntary repatriation with the Mexican and Guatemalan governments. Since then, the Guatemalan government has officially encouraged the refugees to repatriate "dropwise" in smaller groups, under the aegis of the agreement.

Simultaneously, however, Guatemalan refugees began to organize in order to achieve an "organized, collective return," under certain conditions, negotiated by the refugees themselves. In 1987, the forty-five thousand refugees who lived in some one hundred camps in southern Mexico elected representatives for the Permanent Commissions (CCPP) to negotiate, lead and coordinate the return. The Permanent Commissions registered the type and quantity of land properties of the refugees and began the struggle for recognition as a representative body by the Guatemalan government.

Support for the Permanent Commissions fluctuated, but at the end of the day no more than a tenth of the registered refugees opted for "individual" repatriation from 1987 to 1992. In the camps, the distinction between the UNHCR-mediated repatriation (la repatriación) and the Permanent Commissions negotiated return (el retorno) is a crucial one which relates to a complex of other important distinctions among the refugees (e.g., religion and mode of organization).

The distinction is reproduced through discourses on social conduct and moral standards which link el retorno to a normative concept of refugeeness. In this vocabulary, a "real" refugee has suffered violence and dispossession. Shopkeepers, for example, are not real refugees because they "sold their land and their cattle and arrived in Mexico with 1000 Quetzales. They are ahead of us." A real refugee is one who perceives exile as transient and therefore does not become overly attached to life in Mexico. Those who opted for resettlement in more permanent camps in Mexico were said to be planning to stay in Mexico: "Here we are many who want to return to Guatemala; therefore we'll stay and wait [in the present camp]." But real refugees should not repatriate either. They should wait until conditions are ripe for a collective return. As a refugee put it to me in 1988, those who want to go back now, are those who left Guatemala of their own free will. They didn't suffer the war, they just left when they heard something about the war (Kanjobal man, aged forty-eight).

\section{Imagined Return Community}

The "imagined return community" of the Guatemalan refugees is a symbolic construction related to the organization for a collective return. As in other imagined communities, a common history has been constructed; one that emphasizes the struggle of the poor (Indian) for material improvement, autonomy and dignity, against the rich and their army who wanted to break them and take their land. A common future is envisaged, in which the refugees return together, repossess the land, and establish settlements where they can look after each other:

I don't think I'm going back. Not yet.

The flesh is afraid of dying. Who knows if they begin to murder again. And returning like that, alone... there is no security. Only if we all go together, from Quintana, from Campeche, from Chiapas... well, let's go! (Mam woman, aged sixty).

The present is marked by la tristeza, the experience of living with the dilemma of exile as described above, but la tristeza is also used normatively to represent the image of the real refugee who stays and waits. Another important element for the imagined return community are the myths about the solidarity displayed during flight and exile. The need for continued unity and solidarity is often voiced. For those of the adult refugees who had land titles before they fled Guatemala, the repossession of their land is almost an obsession. In the 1970s many of them bought land in newly established cooperatives and settlements in the lowlands close 
to the Mexican border. When they lived in the. Guatemalan highland, they "spent much time wandering in search of land," making their way as day labourers. A sense of prosperity, progress, tranquillity, autonomy and dignity permeates the refugees' narratives about the life they had achieved, a paradise from which they were abruptly expelled.

When the refugees discuss their future in Guatemala, it is hardly possible to distinguish past from future. Return is imagined as a repetition of a familiar theme: the descent from the highland to the virgin lowlands and the transformation from a wandering, landless labourer (also suffering la tristeza) to an autonomous peasant.

\section{"Return is Struggle, not Resignation"}

On October 8, 1992 after five years of negotiations, the Permanent Commissions and the Guatemalan government signed an agreement which guaranteed most of the refugees' demands, including the right to return collectively (i.e., in larger groups than demanded by the government), the right to organize and move freely, exemption from military service for three years, and access to land. However, the Permanent Commissions did not succeed in limiting the army's presence in the area of return.

By February 1994, three groups had returned "organized and collectively" to Guatemala. As groups, they acquired land in the so-called. "peace zone," where, despite its name, confrontations between the army and the guerillas still take place. As the slogan of the return movement foreshadowed, "return is struggle, not resignation." The return process has been an extremely politicized struggle between the Permanent Commissions and the government of Guatemala. Every detail of the practical arrangements contains the potential to disrupt the communication between the parties.

The attitudes of Guatemalan authorities have, in some regards, become more progressive since 1985-86, but many still consider refugees and returnees to be subversives in disguise. The returnees themselves display strong anti-state attitudes. Their imaginations and practices are informed by their experiences with state-terror and more than a decade of life in refugee camps (Stepputat 1989; 1992).

The returnees are trying to create settlements which are relatively autonomous from the state. Some aspects of the present situation may thus bring to mind the "closed corporate community" of the colonial society; but the creation of an imagined return community indicates that they are far beyond that. Apart from the extensive networks of Guatemalan refugees in Canada, the United States, Belize, Mexico, Nicaragua and Honduras, the Permanent Commissions have succeeded in mobilizing the attention and support of the "international community" to a degree unprecedented in Guatemala. The refugees may have become more aware of being "Guatemalans" in exile, but they certainly have become aware of being "citizens of the world." The question is, will they be able to find their home in this world?

\section{References}

Anderson, B. 1983. Imagined Communities. London: Verso.

Redfield, R. 1939. "Primitive merchants of Guatemala." In Quarterly Journal of InterAmerican Relations 1(4).

Said, E. 1984. "The mind of winter: Reflections on life in exile." In Harpers (September): 49-55.

Smith, W. 1977. The Fiesta System and Economic Change. New York: Columbia University Press.

Smith, C. (ed.). 1990. Guatemalan Indians and the State, 1540-1988. Austin: University of Texas Press.

Stepputat, F. 1992. Beyond Relief? Life in a Guatemalan Refugee Settlement in Mexico. Ph.D. dissertation. Copenhagen: Institute of Cultural Sociology, University of Copenhagen.

-1989. Exile and Self-sufficiency in Mexico. UNRISD Discussion Paper No. 9. Geneva. UNRISD.

Wolf, E. 1957. "Closed corporate peasant communities in Mesoamerica and Central Java:" In Southwestern Journal of Anthropology 13(Spring). 0

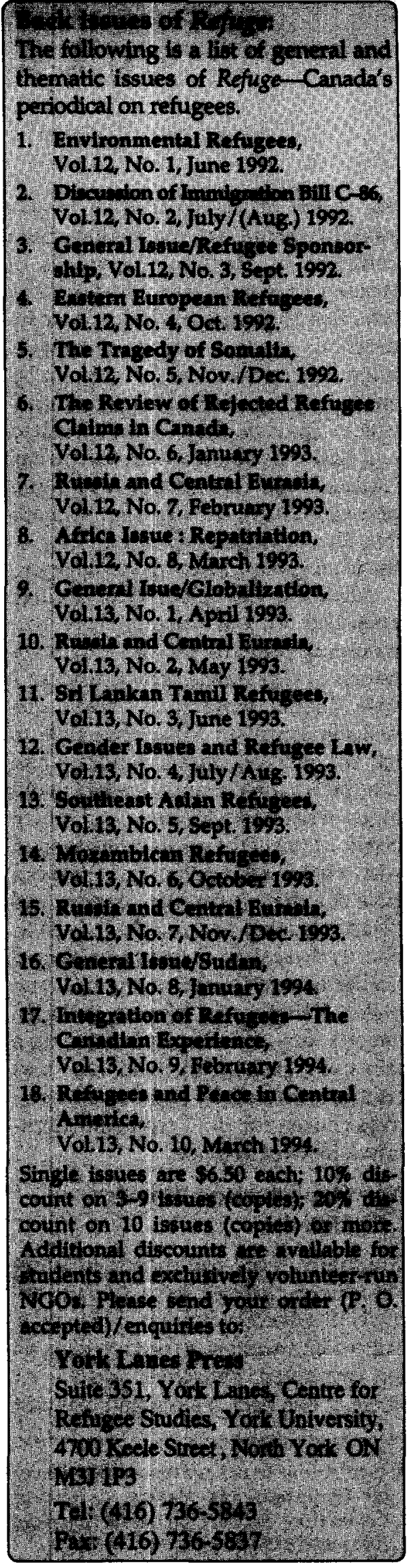

